\title{
Formulasi dan Evaluasi Sediaan Spray GelTabir Surya Fraksi Etil Asetat Daun Cempedak (Artocarpus integer (Thunb.) Merr.) dengan Kombinasi Basis HPMC dan Karbopol 940
}

\author{
Formulation and Evaluation of Sunscreen Spray Gel Preparations Ethyl \\ Acetate Fraction of Cempedak Leaves (Artocarpus Integer (Thunb.) \\ Merr.) with a Combination of HPMC and Karbopol 940 Bases
}

\author{
Salwa*, Mujtahid Bin Abd Kadir, Yuni Sulistyowati \\ Prodi Farmasi/FIK - Universitas Kadiri, Kediri \\ Jl. Selomangleng No. 01, Kota Kediri \\ Email: salwaafra1@gmail.com
}

\begin{abstract}
ABSTRAK
Daun cempedak memiliki aktivitas antioksidan dan mengandung metabolit sekunder berupa senyawa flavonoid yang diketahui mempunyai potensi sebagai tabir surya karrena adanya gugus kromoofor (ikatan rangkap tunggal terkonjugasi) yang mapu menyerap sinar UV. Bentuk sediaan Spray gel merupakan pengembangan dari bentuk sediaan gel yang memiliki tingkat kontaminasi rendah, waktu kontak yang lebih lama dan lebih praktis digunakan. Oleh karena itu, pada penelitian ini akan dilakukan formulasi sediaan spray gel dengan fraksi etil asetat daun cempedak (Artocarpus interger (Thunb.)Merr.). Pada penelitian ini dilakukan formulasi sediaan spray gel dengan variasi perbandingan konsentrasi basis HPMC dan Karbopol 940 berturut-turut $(0,5: 0,5) ;(0,5: 1,0)$ dan $(1,0: 0,5)$. Sediaan yang dibuat kemudian dilakukan evaluasi fisik yang terdiri dari uji organoleptik, homogenitas, $\mathrm{pH}$, viskositas, dan pola penyemprotan. Sedangkan untuk aktivitas tabir surya dilakukan pengujian nilai SPF secara in vitro. Berdasarkan hasil pengujian yang dilakukan didapatkan bahwa formula I memurpakan formula yang paling optimal diantara ketiga formula dengan perbandingan konsentrasi basis HPMC dan karbopol 940 0,5:0,5. Sedangkan pada penentuan nilai SPF diketaruhi sediaan yang memiliki nilai SPF dari yang tertinggi hingga terrendah berturut-turut yaitu formula I $(2,186)$; formula II $(2,141)$ dan formula III $(1,870)$.
\end{abstract}

Kata Kunci : SPF (Sun Protection Factor), Daun cempedak, Artocarpus integer (Thunb.) Merr., Antioksidan, Spray gel

\section{ABSTRACT}

Cempedak leaves have antioxidant activity and contain secondary metabolites in the form of flavonoid compounds that are known to have the potential as carrena sunscreens in the absence of chromoophorus groups (conjugated single double bonds) that absorb UV light. Spray gel ready form is a development of gel ready form that has low contamination rate, longer contact 
time and more practical use. Therefore, in this study will be done a formulation of spray gel available with ethyl acetate fraction of cempedak leaves (Artocarpus interger (Thunb.) Merr.). In this study, spray gel formulations were conducted with variations in the ratio of hpmc and carbopol 940 base concentrations $(0.5: 0,5) ;(0.5: 1,0)$ and $(1,0: 0,5)$. The available is then carried out a physical evaluation consisting of organoleptik testing, homogeneity, $\mathrm{pH}$, viscosity, and spraying pattern. As for sunscreen activity, SPF value testing is done in vitro. Based on the results of the test obtained that formula I murmurs the most optimal formula between the three formulas with a comparison of hpmc base concentration and carbopol 940 0.5:0,5. While the determination of SPF value is affected by the available that has an SPF value from the highest to the lowest in a row namely formula I $(2,186)$; formula II $(2,141)$ and formula III $(1,870)$.

Keywords: SPF (Sun Protection Factor), Cempedak leaves, Artocarpus integer (Thunb.) Merr., Antioxidant, Spray gel

\section{PENDAHULUAN}

Indonesia merupakan salah satu negara tropis dimana pengaruh sinar matahari sangat besar terhadap kehidupan. Makhluk hidup sangat membutuhkan sinar matahari untuk kelangsungan hidupnya. Selain itu manusia juga membutuhkan sianar matahari selain sebagai sumber energi juga sebagai untuk menjaga kesehatannya, sebagai contoh dalam pembentukan Vitamin D maupun sebagai sumber Pro-vitamin D yang dapat mencegah penyakit polio atau riketsia (Ismail, dkk., 2014). Akan tetapi sinar matahari yang sampai dipermukaan selain memiliki manfaat juga berdampak negatif terhadap kulit yang berasal dari sinar UV A dan UV B (Shovyana dkk., 2013). Secara alami kulit manusia memiliki mekanisme pertahanan sendiri terhadap dampak negatif terhadap paparan sinar matahari misalnya dengan cara mengeluarkan keringat, pembentukan melanin, maupun penebalan stratum korneum. Selain itu tubuh manusia juga dilengkapi dengan perlindungan alami terhadap sinar matahari yang berbahaya. Perlindungan alami yang dimiliki kulit ini berupa enzim antioksidan (Superoksida dismutase, Katalase, Glutation peroksidase), maupun molekul non enzim (Vitamin C, Vitamin E, Glutation, Ubiquinone) serta kemampuan pigmentasi kulit (Suryaputra, 2015).

Paparan sinar matahari yang berlebih dapat diatasi dengan berbagai cara, salah satunya dengan menggunakan sediaan tabir surya. Sediaan tabir surya adalah suatu sediaan kosmetik yang memiliki kemampuan untuk menghambat penetrasi sinar UV ke dalam kulit. Senyawa tabir surya yang terdapat di alam, misalnya senyawa fenol yang terkandung di dalam tumbuhan yang memiliki fungsi untuk melindungi jaringan tanaman terhadap kerusakan akibat radiasi sinar matahari (Shovyana, dkk., 2013). Bahan alam digunakan untuk menurunkan radiasi yang dipancarkan sinar matahari serta meningkatkan 
perlindungan kulit terhadap dampak negatif radiasi sinar matahari pada kulit menjadi fokus dalam beberapa penelitian (Whenny, dkk., 2015).

Daun Cempedak merupakan daun yang sering digunakan oleh masyarakat di khususnya di wilayah Kalimantan sebagai bedak dingin dan penghilang flek hitam pada wajah. Diketahui kstrak maupun fraksi etil asetat Daun Cempedak mengandung senyawa antioksidan dan metabolit sekunder berupa Flavonoid (Rahmawati, 2013). Senyawa metabolit sekunder seperti flavonoid, Tanin, Antarquinon dan lain-lain telah diketahui memiliki kemampuan perlindungan terhadap sinar UV (Ismail, dkk., 2014). Sejauh ini telah diketahui bahwa senyawa fenolik khususnya golongan flavonoid dan tanin memiliki potensi untuk digunakan sebagai tabir surya karena memiliki senyawa gugus kromofor (ikatan rangkap yang terkonjugasi) sehingga mampu menyerap sinar UV baik UV A maupun UV B (Shovyana, dkk., 2013).

Menurut FDA (Food Drug Administration) pembagian kemampuan tabir surya/ SPF (Sun Protection Factor) adalah Minimal (SPF 2-4), Sedang (SPF 4-6), Ekstra (SPF 6-8), Maksimal (SPF 8-15), dan Ultra (jika SPF lebih dari 15) (Damogalad, 2013).

Sejauh ini bentuk sediaan topikal di pasaran yang sering digunakan sebagai tabir surya yaitu bentuk krim, gel, dan lotion. Belum banyak produk yang membuat sediaan tabir surya dalam bentuk spray apalagi yang terbuat dari bahan alam. Bentuk spray dipilih atas dasar sifat spray yang dapat memberikan suatu kandungan yang konsentrat, tetapi pada saat yang bersamaan juga memiliki kemampuan cepat menjadi kering sehingga dapat memberikan pengalaman yang menyenangkan dan mudah dipakai untuk pengguna. Sediaan spray gel memiliki kelebihan yaitu lebih aman, lebih praktis penggunaannya, dan lebih mudah dicuci jika dibandingkan dengan sediaan topical lainnya. Oleh karena itu peneliti tertarik ingin melakukan penelitian tentang, formulasi spray gel tabir surya dengan bahan aktif Fraksi Etil Asetat Daun Cempedak.

\section{METODE PENELITIAN}

\section{Tempat dan Waktu Penelitian}

Penelitian ini akan dilaksanakan di Laboratorium Farmasi yaitu di Laboratorium Teknologi dan Intrumentrasi Program Studi Farmasi Universitas Kadiri. Penelitian ini dilaksanakan mulai dari Desember 2019 sampai Agustus 2020.

\section{Alat dan Bahan}

Peralatan yang digunakan dalam penelitian ini adalah mortir dan stamper, neraca analitik (FUJITSU), cawan porselin (PYREX), batang pengaduk, spatula, alumunium foil, beaker glass (PYREX), kaca arloji (PYREX), corong pisah (PYREX), pH meter (Mettler Toledo), viscometer (Viskometer Brookfield DV2T), oven digital, lemari pendingin, spektrofotometer UV-Vis (Thermo), kuvet, pipet tetes, botol semprot, plastik mika, botol kaca gelap, gelas ukur $100 \mathrm{~mL}$, dan kertas perkamen. Bahan yang digunakan dalam penelitian ini adalah Daun Cempedak (Artocarpus integer (Tunb.) Merr.) segar berwarna hijau sebanyak 3 
kg yang diperoleh dari perkebunan di Banjarmasin, Etil asetat (Brataco, Indonesia), Aquadest (Brataco, Indonesia), Karbopol 940 (Brataco, Indonesia) , HPMC (Kingcel), Propilenglycol (Lansida), Metil paraben (SKJ), Propyl paraben (SKJ), Trietanolamin (Merck), n-heksana (Merck) dan Etanol 96\% (One Med).

\section{Prosedur Penelitian}

Penelitian ini dimulai dari proses pengumpulan bahan simplisia Daun Cempedak (Artocarpus integer (Tunb.) Merr.) yang diperoleh dari perkebunan di Banjarmasin, Kalimantan Selatan. Daun cempedak (Artocarpus integer (Tunb.) Merr.) yang telah dikeringkan kemudian ditimbang sebanyak 500 gram dan dimaserasi dengan etanol 96\% selama 3 × 24 jam menggunakan pelarut yang diperbaharui setiap 24 jam (remaserasi). Filtrat yang telah terkumpul kemudia di uapkan hingga $50 \%$ dan selanjutnya dilakukan penyederhanaan senyawa berdasarkan sifat kepolaran dengan metode ECC (fraksinasi) menggunakan pelarut n-heksan (non polar) dan etil asetat (semi polar). Fraksi Etil Asetat kemudian dikentalkan menggunakan waterbath dengan suhu $40^{\circ} \mathrm{C}$ untuk menghilangkan pelarut Etil Asetat hingga didapatkan ekstrak kental fraksi Etil Asetat Daun Cempedak. (Fitriansyah, dkk., 2016). Fraksi etil asetat yang didapatkan kemudian dipekatkan hingga menjadi kental dengan cara diuapkan kemudian dilakukan formulasi dalam 3 formula dengan variasi konsentrasi basis gel karbopol 940 dan HPMC. Bahan-bahan kemudian ditimbang dengan neraca analitik kecuali Trietanolamin. Karbopol 940 didispersikan dengan Aquadest hingga terdispersi seluruhnya, kemudian ditambahkan Trietanolamin hingga terbentuk massa gel yang transparan HPMC didispersikan dengan Aquadest hingga terbentuk massa gel transparan yang memiliki konsistensi cukup kental. Metil paraben dan Propil paraben dilarutkan dengan Propylenglycol. Karbopol 940 dan HPMC di campurkan hingga homogen ke dalam gelas beker, kemudian ditambahkan campuran Metil paraben dan Propil paraben yang dilarutkan dengan Propylenglycol, fraksi etil asetat Daun Cempedak dan Aquadest, aduk menggunakan batang pengaduk hingga homogen. Masukkan sediaan ke dalam wadah spray (Sihombing dan Lestari, 2016).

Tabel 1 Formula Spray Gel Tabir Surya Fraksi Etil Asetat Daun Cempedak

\begin{tabular}{lccc}
\hline \multirow{2}{*}{\multicolumn{1}{c}{ Bahan }} & \multicolumn{3}{c}{ Formula } \\
\cline { 2 - 4 } & F1 & F2 & F3 \\
\hline Fraksi etil asetat & 0,25 & 0,25 & 0,25 \\
\hline Karbopol 940 & 0,50 & 1,00 & 0,50 \\
\hline HPMC & 0,50 & 0,50 & 1,00 \\
\hline Propilenglycol & 10,00 & 10,00 & 10,00 \\
\hline Metil paraben & 0,18 & 0,18 & 0,18 \\
\hline Propyl paraben & 0,02 & 0,02 & 0,02 \\
\hline Trietanolamin & $8 \mathrm{gtt}$ & $12 \mathrm{gtt}$ & $8 \mathrm{gtt}$ \\
\hline Aquadest ad & 100,0 & 100,0 & 100,0 \\
\hline
\end{tabular}




\section{Evaluasi Sifat Fisik}

Sediaan spray ge/yang telah dibuat kemudian di evaluasi dengan

1. Pemeriksaan Organoleptik

Pengamatan organoleptik dilakukan dengan mengamati penampakan sediaan secara kasat mata seperti warna, bau, kejernihan, pemisahan dan perubahan-perubahan lainnya yang mungkin terjadi setelah pembuatan (Martono dan Suharyani, 2018).

2. Pemeriksaan Homogenitas

Pemeriksaan homogenitas pada formulasi sediaan dilakukan dengan cara mengoleskan sediaan untuk setiap formulanya diatas kaca objek dan diamati sebaran partikel yang terbentuk secara visual untuk partikel yang tidak larut. Untuk setiap formula pengamatan dilakukan replikasi sebanyak 3 kali (Martono dan Suharyani, 2018).

3. Pengukuran $\mathrm{pH}$

Sediaan spray gel diukur $\mathrm{pH}$ nya menggunakan $\mathrm{pH}$ meter yang telah di kalibrasi pada larutan buffer $\mathrm{pH} \mathrm{4,7}$ dan 10. Pemeriksaan $\mathrm{pH}$ dilakukan untuk mengamati stabilitas $\mathrm{pH}$ apakah masih dalam rentang persyaratan $\mathrm{pH}$ sediaan topikal atau tidak (4,5-7) untuk menjamin sediaan tidak akan menyebabkan iritasi pada kulit (Martono dan Suharyani, 2018).

4. Pengukuran Viskositas

Sediaan disiapkan dalam gelas beker $100 \mathrm{~mL}$, kemudian dilakukan pemilihan spindel yang sesuai pada masing-masing formula, lalu kecepatan disetel 30 rpm dan dicelupkan ke dalam sediaan sampai alat menunjukkan nilai viskositas sediaan. Nilai viskositas (cPs) yang ditunjukkan pada alat viskometer merupakan nilai viskositas sediaan. Pengukuran viskositas dilakukan dengan replikasi 3 kali (Fitriansyah, dkk., 2016).

5. Pemeriksaan Pola Penyemprotan dan Bobot per Semprot

Sediaan disemprotkan pada lembaran plastik yang sudah diukur beratnya dan diberi nomor dengan jarak semprot $3 \mathrm{~cm}, 5 \mathrm{~cm}, 10 \mathrm{~cm}, 15 \mathrm{~cm}$, dan 20 $\mathrm{cm}$ lalu diukur waktu pengeringan menggunakan dan ditimbang beratnya. Pengujian setiap jarak dilakukan secara triplo, pada uji ini yang diamati adalah pola pembentukan hasil semprotan, diameter pola penyeemprotan yang terbentuk, dan jumlah sediaan yang keluar (gram) tiap semprotnya dengan jarak yang sama (Suyudi, 2014).

6. Pemeriksaan Stabilitas Sediaan

Sediaan diletakkan pada suhu dingin $\left(4 \pm 2^{\circ} \mathrm{C}\right)$ selama 48 jam dilanjutkan dengan meletakkan sampel sediaan pada suhu panas $\left(40 \pm 2^{\circ} \mathrm{C}\right)$ selama 48 jam (1 siklus). Pengujian dilakukan sebanyak 3 siklus dan diamati terjadinya perubaha fisik dari sediaan spray gel pada awal dan akhir siklus yang meliputi organoleptis, homogenitas, viskositas dan pH (Suyudi, 2014).

\section{Evaluasi nilai SPF}

Sediaan spray gel fraksi etil asetat Daun Cempedak pada masing-masing formula dilarutkan dalam etanol $96 \%(2 \mathrm{mg} / 2 \mathrm{~mL})$. Serapan dari setiap sampel uji 
ditentukan pada spektrofotometer UV-Visible pada panjang gelombang $290 \mathrm{~nm}$ sampai $320 \mathrm{~nm}$. Pembacaan nilai adsorbansi setiap interval 5 dari panjang gelombang $290 \mathrm{~nm}$ sampai panjang gelombang 320 nm (Lolo dkk., 2017). Untuk menentukan nilai SPF digunakan rumus :

$\mathrm{SPF}=\mathrm{CF} \times \sum_{290}^{320} \times \mathrm{Abs} \times \mathrm{EE} \times \mathrm{I}$

Keterangan :

$\mathrm{CF} \quad=$ Faktor Koreksi

$\mathrm{EE} \quad=$ Efisiensi Eriterma

I $=$ Spektrum Intensitas dari Matahari

Abs $=$ Adsorbansi dari Sampel

\section{HASIL DAN PEMBAHASAN}

Dari proses maserasi yang telah dipekatkan didapatkan ekstrak seberat 89 gram dengan rendemen 17,8 \%. Rendemen suatu ekstrak ditentukan oleh berbagai macam faktor, diantarnya yaitu metode ekstraksi yang digunakan, pelarut yang digunakan, suhu pelarut ekstraksi, maka semakin banyak ekstrak yang dihasilkan semakin tinggi nilai rendemen yang didapatkan. Hasil ekstraksi kemudian difarkasinasi dengan $n$-heksan. Fraksinasi memiliki prinsip memisahkan senyawa-senyawa berdasarkan perbedaan sifat kepolaran. Untuk memisahkan senyawa yang bersifat non polar dari ekstrak digunakan pelarut n-heksan karena n-heksan merupakan jenis pelarut non polar sehingga senyawa yang sifatnya non polar akan ikut terlarut (Maulida dan Zulkarnaen, 2010), kemudian dilakukan penarikan senyawa aktif flavonoid yang larut dalam pelarut semi polar etil asetat (Whenny, dkk., 2015). Hasil dari fraksinasi didapatkan ekstrak 6,6 gram dengan rendemen $7,41 \%$.

Berdasarkan proses skrining fitokimia yang telah dilakukan terhadar ekstrak hasil maserasi daun cempedak diketahui bahwa ekstrak etanol daun cempedak mengandung senyawa metabolit sekunder Alkaloid, Flavonoid, Tanin, Saponin dan juga senyawa Triterpenoid, sedangkan hasil fraksi etil asetat daun cempedak hanya mengandung senyawa Alkaloid, Flavonoid, dan juga senyawa golongan Triterpenoid.

Kemudian hasil pengujian evaluasi sifat fisik spray gel yang telah diformulasi didapatkan hasil sebagai berikut:

\section{Hasil uji Organoleptik}

Berdasaran uji organoleptik untuk formula ke 1 hingga formula ke 3 tidak begitu kelihatan perbedaan yang signifikan yaitu warna yang dimiliki formulas I, II, dan III menunjukkan warna merah muda karena jumlah fraksi etil asetat daun cempedak yang digunakan sedikit. sementara itu pada formula I memiliki konsistensi yang lebih cair dibandingkan formula II, maupun III hal ini karena perbedaan perbandingan konsentrasi antara HPMC dan Karbopol 940 yang digunakan. 
Tabel 2 Hasil Pengujian Organoleptik

\begin{tabular}{cccc}
\hline \multirow{2}{*}{ Tampilan fisik } & \multicolumn{3}{c}{ Formula } \\
\cline { 2 - 4 } & I & II & III \\
\hline Warna & Merah muda & Merah muda & Merah muda \\
\hline Bau & Tidak berbau & Tidak berbau & Tidak berbau \\
\hline Bentuk & Cukup kental & Kental & Kental \\
\hline
\end{tabular}

\section{Hasil uji Homogenitas}

Dari hasil pengujian yang dilakukan pada setiap formula menunjukkan homogenitas yang baik atau tidak terjapat gumpalan partikel. HPMC maupun Karbopol 940 yang digunakan sudah mengembang dengan baik pada saat proses penggerusan dengan menggunakan aquadest panas (70 - 80 ${ }^{\circ} \mathrm{C}$ ) sehingga saat dicampurkan dengan eksipien yang lainnya maka akan terbentuk massa gel yang baik pula.

Tabel 3 Hasil Uji Homogenitas

\begin{tabular}{cc}
\hline Formula & Homogenitas \\
\hline I & Homogen \\
\hline II & Homogen \\
\hline III & Homogen \\
\hline
\end{tabular}

\section{Hasil uji pH}

Dari hasil pengukuran $\mathrm{pH}$ yang dilakukan menunjukkan rata-rata $\mathrm{pH}$ seluruh formula memenuhi syarat karena masuk dalam rentang $\mathrm{pH}$ yang dipersyaratkan. pH sediaan yang dibuat dipengaruhi oleh konsentrasi TEA yang digunakan, TEA merupakan bahan pembasah yang digunakan untuk menetralkan Karbopol 940 agar tidak menjerat udara sehingga spray gel yang dihasilkan tidak bergelembung.

Tabel 4 Hasil Uji pH

\begin{tabular}{cccc}
\hline \multirow{2}{*}{ Pengujian } & \multicolumn{3}{c}{ Formula } \\
\cline { 2 - 4 } & I & II & III \\
\hline 1 & 5,99 & 6,59 & 6,36 \\
\hline 2 & 5,15 & 6,53 & 6,35 \\
\hline 3 & 5,76 & 6,55 & 6,36 \\
\hline Rata-rata & 5,63 & 6,55 & 6,35 \\
\hline
\end{tabular}

\section{Hasil Uji Viskositas}

Dari hasil pengujian viskositas formula I memiliki viskositas yang baik atau sesuai sebagai sediaan spray gel dengan basis HPMC dan Karbopol 940 dalam perbandingan $1: 1(0,5: 0,5)$ sedangkan pada formula II dan III memiliki viskositas yang lebih tinggi, sehingga sulit dilakukan penyemprotan. Kombinasi HPMC dan Karbopol 940 dapat meningkatkan viskositas sediaan spray gel dimana viskositas Karbopol 940 dipengaruhi nilai Ph dimana pH antara 5 hingga 7 maka Karbopol 940 akan mengalai proses gelling atau dalam keadaan konsistensi gel yang juga memiliki viskositas tinggi. 
Tabel 5 Hasil Uji Viskositas

\begin{tabular}{cccc}
\hline \multirow{2}{*}{ Pengujian } & \multicolumn{3}{c}{ Viskositas (cPs) } \\
\cline { 2 - 4 } & I & II & III \\
\hline 1 & 980 & 2400 & 2400 \\
\hline 2 & 1000 & 2350 & 2380 \\
\hline 3 & 1050 & 2630 & 2400 \\
\hline Rata-rata & 1010 & 2460 & 2393 \\
\hline
\end{tabular}

\section{Hasil uji Pola Penyemprotan}

Berdasarkan uji pola penyemprotan yang dilakukan terhadap formula I, II, dan III menunjukkan hasil yang bervariasi, hal ini dipengaruhi oleh berbagai factor. Pada formula I cenderung memiliki diameter semprot yang lebih lebar dibandingkan formula II dan III hal ini dipengaruhi oleh viskositas pada spray gel formula I yang lebih rendah sehingga menghasilkan pola penyebaran yang lebih luas, selain itu pada formula I juga memiliki bobot semprot yang lebih sedikit karena ukuran partikelnya lebih kecil namun lebih tersebar merata. Hasil uji pola penyemprotan dapat dilihat pada Tabel 3.5.

\section{Hasil Uji Stabilitas}

Pengamatan yang dilakukan mencakup pengamatan organoleptik sediaan, setelah 48 jam penyimpanan pada suhu ruangan sediaan terpantau stabil dan tidak terdapat perubahan, setelah 7 hari penyimpanan terjadi perubahan pada warna sediaan yang menjadi lebih gelap dan mulai timbul gelembung udara. Hal ini menunjukkan bahwa gel belum stabil pada penyimpanan diatas waktu 48 jam atau 2 hari.

Tabel 6 Hasil Uji Pola Penyemprotan

\begin{tabular}{cccc}
\hline Jarak semprot & Formula I & Formula II & Formula III \\
\hline \multicolumn{4}{c}{ Pola penyemprotan } \\
\hline $3 \mathrm{~cm}$ & Menggumpal & menggumpal & Menggumpal \\
\hline $5 \mathrm{~cm}$ & Menggumpal & menggumpal & Menggumpal \\
\hline $10 \mathrm{~cm}$ & Menggumpal & menggumpal & Menggumpal \\
\hline $15 \mathrm{~cm}$ & Menggumpal & menggumpal & Menggumpal \\
\hline $20 \mathrm{~cm}$ & Menggumpal & menggumpal & Menggumpal \\
\hline \multicolumn{4}{c}{ Diameter Semprot (cm) } \\
\hline $3 \mathrm{~cm}$ & 0,9 & 0,05 \\
\hline $5 \mathrm{~cm}$ & 2,1 & 0,07 & 0,08 \\
\hline $10 \mathrm{~cm}$ & 2,6 & 0,05 & 0,09 \\
\hline $15 \mathrm{~cm}$ & 3,4 & 0,4 & 0,06 \\
\hline $20 \mathrm{~cm}$ & 5,5 & 0,5 \\
\hline \multicolumn{4}{c}{0,05} \\
\hline $3 \mathrm{~cm}$ & Bobot Tetesan (gram) \\
\hline $5 \mathrm{~cm}$ & 0,06 & 0,08 & 0,21 \\
\hline $10 \mathrm{~cm}$ & 0,04 & 0,12 & 0,11 \\
\hline $15 \mathrm{~cm}$ & 0,05 & 0,11 & 0,08 \\
\hline $20 \mathrm{~cm}$ & 0,07 & 0,11 & 0,13 \\
\hline \multicolumn{4}{c}{0,11} \\
\hline
\end{tabular}


Tabel 7 Hasil pengamaatan stabilitas sediaan

\begin{tabular}{cccc}
\hline \multirow{2}{*}{ Hari ke- } & \multicolumn{3}{c}{ Formula } \\
\cline { 2 - 4 } & I & II & III \\
\hline 0 & $(++)$ & $(++)$ & $(++)$ \\
\hline 2 & $(++)$ & $(++)$ & $(++)$ \\
\hline 7 & $(+)$ & $(+)$ & $(+)$ \\
\hline 14 & $(-)$ & $(-)$ & $(-)$ \\
\hline
\end{tabular}

Keterangan :

$(++)$ : Sediaan memiliki warna, bau, dan bentuk yang baik

(+) : Sediaan baik tetapi mengalami perubahan warna

$(-) \quad$ : Sediaan mengalami perubahan warna, konsistensi dan berair

\section{Hasil Evaluasi Nilai SPF}

Dari pengujian dan perhitungan nilai SPF terhadap fraksi etil asetat daun cempedak yang telah diformulasi kedalam bentuk sediaan spray gel memiliki aktivitas proteksi terhadap sinar UV dengan nilai SPF tertinggi pada formula I $(2,186)$ yang termasuk kedalam tipe proteksi minimal, sementara itu pada formulasi II memiliki 2,141 juga termasuk proteksi minimal. Selain itu berdasarkan hasil uji sifat fisik diketahui bahwa formula I memiliki viskositas dan pola penyemprotan yang lebih baik dibandingkan formula II, dan III. Hasil uji nilai SPF pada formula I, II, dan III dapat dilihat pada Gambar 3.1.

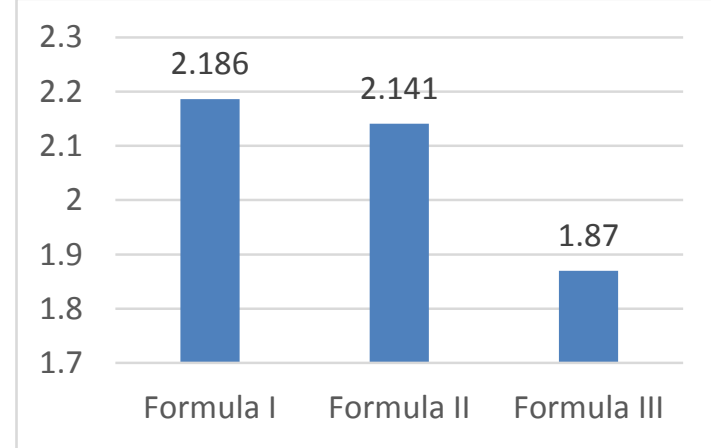

Gambar 1. Nilai SPF Spray gel

\section{KESIMPULAN DAN SARAN Kesimpulan}

Formulasi spray gel tabir surya fraksi etil asetet daun cempedak dengan kombinasi basis HPMC dan Karbopol 940 menghasilkan spray gel dengan sifat fisik yang kurang baik pada ketiga formula tetapi masih memiliki aktivitas sebagai tabir surya atau SPF pada formula I dan II.

Fraksi etil asetat daun cempedak dapat diformulasi dalam bentuk sediaan spray gel dengan kemampuan sebagai tabir surya yang memiliki nilai SPF terbaik pada formula I $(2,186)$ dan formula II $(2,141)$ atau dengan kategori proteksi minimal sedangkan pada formula III $(1,87)$ atau tidak memenuhi standar proteksi SPF menurut Food Drug Administration (FDA). 


\section{Saran}

Sebaiknya dilakukan pengembangan dalam hal formulasi sediaan agar didapatkan formula sediaan spray gel yang memiliki kriteria sifat fisik yang lebih baik dan memiliki stabilitas yang baik pada penyimpanan, dan sebaiknya digunakan komposisi ekstrak yang lebih tinggi konsentrasinya agar didapatkan sediaan tabir surya dengan kemampuan proteksi yang lebih baik.

\section{DAFTAR PUSTAKA}

Andarina, R., \& Djauhari, T. (2017). Antioksidan dalam dermatologi. Jurnal Kedokteran Kesehatan: Publikasi IImiah Fakultas Kedokteran Universitas Sriwijaya, 4 (1), 39-48.

Anggraini Septi, Nur Mita, dan Arsyik Ibrahim. Formulasi Krim Antioksidan Daun Cempedak (Artocarpus champeden Spreng). Laboratorium Penelitian dan Pengembangan FARMAKA TROPIS Fakultas Farmasi Universitas Mulawarman, Samarinda, Kalimantan Timur. 2015.

Arsyad, A. B. (2014). Analisis pengaruh waktu pemanasan terhadap degradasi aktivitas antioksidan pada daun kangkung air (Ipomoea Aquatica Forsk) (Doctoral dissertation, UIN Walisongo).

Barel, A.O., Paye, M., and Maicbach, H.I. (2001). Handbook of Cosmetic Science and Technology. New York: Marcel Dekker. Hal. 131, 582, 718.

Bhat, S. V., B. A. Nagasampagi and S. Meenakshi. 2009. Natural Products :Chemistry and Application. Narosa Publishing House. New Delhi. India

Chandra, Boy., Rezza Puspita Sari, Sestry Misfadhila, Zikra Azizah, Ridho Asra. Phytochemical Screening And Antioxidant Activities Of Kemangi Leaf (Ocimum Tenuiflorum L.) Methanol Extract Using Dpph (1,1-Diphenyl-2Picrylhydrazine) Method. Journal Of Pharmaceutical And Sciences, Vol.2, No. 2.2019.pp. 1-8.

Damogalad, V., Hosea Jaya Edy dan Hamidah Sri Supriadi. Formulasi Krim Tabir Surya Ekstrak Kulit Nanas (Ananas comosus L Merr) dan Uji In Vitro Nilai Sun Protecting Factor (SPF). Pharmacon Jurnal Ilmiah Farmasi UNSRAT Vol. 2 No. 2. Manado : Program Studi Farmasi FMIPA UNSRAT, 2013.

Dewi, Christine Citra, dan Nyi Mekar Saptarini. Review Artikel : Hidroksi Propil Metil Selulosa Dan Karbomer Serta Sifat Fisikokimianya Sebagai Gelling Agent. Farmaka. Vol. 14 No.3. Fakultas Farmasi UNPAD.

Ditjen POM. (2000). Parameter Standar Umum Ekstrak Tumbuhan Obat. Cetakan Pertama. Jakarta: Departemen Kesehatan Republik Indonesia. Hal: 26, 28, 122, 124.

Fitmawati, F., \& Sofiyanti, N. (2015). Analisis Hubungan Kekerabatan Cempedak (Artocarpus Champaden Lour.) Berdasarkan Penanda Morfologi Di Kabupaten Kampar Provinsi Riau. Jurnal Online Mahasiswa Fakultas Matematika dan Ilmu Pengetahuan Alam Universitas Riau, 2 (1), 153-160.

Fitriansyah, S.N., Sohadi Wirya, Cici Hermayanti. Formulasi Dan Evaluasi Spray Gel Fraksi Etil Asetat Pucuk Daun Teh Hijau (Camelia Sinensis [L.] Kuntze) Sebagai Antijerawat. PHARMACY, Vol.13 No. 02 Desember 2016. 
Holland, Troy., Hassan, Chaouk, Bruktawif Aswaf, Stephen Goodrich, Adrian Hunter, dan Vimala Francis. 2002. Spray Hidrogel Wound Dressing.

United State Patent Aplication Publication.

Ismail Isriany, Gemy Nastity Handayany, Dwi Wahyuni, dan Juliandri. Formulasi dan Penentuan Nilai SPF (Sun Protecting Factor) Sediaan Krim Tabir Surya Ekstrak Etanol Daun Kemangi (Ocimum Sanctum L.). JF FIK UIN Alauddin Makassar Vol 2 No.1. 2014.

Jauregui K.M., dkk. 2009. A New Formulated Stable Papin-Pectin Aerosol Spray for Skin Wound Healing. Biotechnology and Bioprocess Engineering. Vol. $14: 450-456$.

Kalangi, S. J. (2013). Histofisiologi kulit. Jurnal Biomedik, 5(3).

Kamishitta, Takuzo, Takashi Miyazaki, Yoshihide Okuno. 1992. Spray Gel Base and Spray Gel Preparation Using There of. United State Patent Aplication Publication. Amerika.

Lolo, W.A., Sri Sudewi, Hosea Jaya Edy. Determination Sun Protecting Factor (SPF) Of Krokot Herbs Extract (Portulacaoleracea L.). Journal of Pharmaceutical Science and Clinical Research, 2017, 02, 01 - 05.

Mardiana, Z. H. (2015). Formulasi Gel Yang Mengandung Lendir Bekicot (Achatina Fulica) Serta Uji Aktivitas Antibakteri Terhadap Propionibacterium Acnes.

Martono, Cep, Ine Suharyani. Formulasi Sediaan Spray Gel Antiseptik Dari Ekstrak Etanol Lidah Buaya (Aloe Vera). Jurnal Farmasi Muhammadiyah Kuningan. 3.(1). 2018.

Nisak, Khoirun. 2016. Uji Stabilitas Fisik dan Kimia Sediaan Gel Semprot Ekstrak Etanol Tumbuhan Paku (Nephrolepis falcata (Cav.) C. Chr.) Jakarta: Fakultas Kedokteran dan Ilmu Kesehatan, UIN Syarif Hidayatullah Jakarta.

Novia, Dewi., Yuska Noviyanti, Yansi Noves Anggraini. Identifikasi Dan Fraksinasi Ekstrak Akar Tebu Hitam (Saccharum Officinarum L.) Dengan Metode Kromatografi Lapis Tipis. Jurnal Ilmiah Farmacy, Vol. 6 No.1, Maret 2019.

Puspitasari, L., Swastini, D. A., \& Arisanti, C. I. S. (2013). Skrining fitokimia ekstrak etanol 95\% kulit buah manggis (Garcinia mangostana L.). Jurnal Farmasi Udayana.

Rahmawati, Dwi. 2013. Uji Aktivitas Antioksidan dan Identifikasi Metabolit Sekunder Batang dan Daun Cempedak (Artocarpus champeden Spreng). Skripsi. Fakultas Farmasi Universitas Mulawarman. Samarinda.

Redha, A. (2013). Flavonoid:Struktur, Sifat Antioksidatif Dan Peranannya Dalam Sistem Biologis. Politeknik Negeri Pontianak.

Romadhoni, Febrina Putri. 2017. Isolasi Pektin Dari Kulit Pisang Kepok (Musa Balbisiana ABB) Dengan Metode Refluks Menggunakan Pelarut HCL Encer. Palembang: Politeknik Negeri Sriwijaya Palembang.

Rowe, C. R., Sheskey, J. P., and Weller, J. P., 2009, Handbook of Pharmaceutical Excipients, 5th Edition, 18-19, 89- 91, 462-469, 629-631, American Pharmaceutical Association, London, Chicago. 
Rusita Dwi Youstiana dan Suhendriyo. Uji Aktifitas Tabir Surya Dan Stabilitas Fisik Formula Gel Semprot Dari Ekstrak Temugiring (Curcuma heyneana Val.) Dan Ekstrak Kayu Manis (Cinnamomum burmanii Nees.) Dengan ,Kombinasi Karbopol Dan HPMC. Kementrian Kesehatan Politeknik Kesehatan Surakarta Jurusan Jamu Vol 6 No.2. 2017

Shafira, U., Gadri, A., Lestari, F. 2015. Formulasi sediaan spray gel serbuk getah tanaman jarak cina dengan variasi jenis polimer pembentuk film dan jenis plasticizer. Prosiding Penelitian SPeSIA Unisba 2015. Bandung: Fakultas MIPA Unisba. Hal. 564-566.

Shovyana, H.H., A. Karim Zulkarnain. Physical Stability and Activity of Cream W/O Etanolic Fruit Extract of Mahkota Dewa (Phaleria macrocarpha (scheff.) Boerl,) as A a Sunscreen. Traditional Medicine Journal 18(2). Yogyakarta: Fakultas Farmasi UGM, 2013.

Sihombing, L. N dan Putri Cikal Lestari. Formulasi Dan Evaluasi Sediaan Spray Gel Lidah Buaya (Aloe Vera L.) Dengan Variasi Konsentrasi Carbomer Dan Hpmc. Politeknik Kesehatan Kementrian Kesehatan Bandung, 2016.

Sudarmanto, I., \& Suhartati, T. (2016). Aktivitas Antioksidan Senyawa Flavonoid pada Kulit Akar Tanaman Ara (Ficus racemosa, L). Jurnal Kesehatan, 6(2).

Suryani, N. Citra, D. G. M. Permana, A. A. G. N. Anom Jambe. (2016). Pengaruh Jenis Pelarut Terhadap Kandungan Total Flavonoid Dan Aktivitas Antioksidan Ekstrak Daun Matoa (Pometia pinnata).

Suryaputra, G. (2015). Formulasi Sediaan Tabir Surya Ekstrak Air Buab Stroberi (Fragaria vesca L.) Dalam Bentuk Sediaan Krim (Doctoral dissertation, Widya Mandala Catholic University Surabaya).

Susanti, M. (2012). Aktifitas Perlindungan Sinar UV Kulit Buah Garcinia mangostana Linn Secara In Vitro. Pharmacon: Jurnal Farmasi Indonesia, $13(2), 61-64$.

Suyudi, Salsabiela Dwiyudrisa. 2014. Formulasi Gel Semprot Menggunakan Kombinasi Karbopol 940 dan Hidroksipropil Metilselulosa (HPMC) Sebagai Pembentuk Gel. Jakarta: Fakultas Kedokteran dan Ilmu Kesehatan, UIN Syarif Hidayatullah Jakarta.

Tranggono, R.I.S dan Latifah, F. (2007). Buku Pegangan IImu Pengetahuan Kosmetik. Jakarta: Gramedia Pustaka Utama.

Wasitaatmadja, S. M. (2007). IImu Penyakit Kulit Dan Kelamin. Edisi V. Jakarta: Universitas Indonesia

Whenny, Rolan Rusli, dan Laode Rijai. Aktivitas Tabir Surya Ekstrak Daun Cempedak (Artocarpus Champeden Spreng). Jurnal Sains dan Kesehatan. 2015. Vol 1. No 4.

Wiluajeng, Danik. Formulasi Krim Tabir Surya Mengandung Minyak Biji Gandum (2, 5\%, 5\%, 7, 5\%) Kombinasi Dengan Titanium Dioksida, Oktil Metoksisinamat, Dan Butil Metoksidibenzoilmetan. Diss. University of Muhammadiyah Malang, 2018.

Yuslianti, E. R. 2018. Pengantar Radikal Bebas Dan Antioksidan. CV Budi Utama. Yogyakarta. 